Telegraph" (1857), "The Electric Light" (1881), "Polarized Light" (1881) by Mr. William Spottiswoode, then president of the Royal Society, "The Habits of Ants" (1884) by Sir John Lubbock, "Fireworks. Their Chemistry and Mechanics" (1886) by C. V. Boys, "An Evening with the Telescope" (1896) by Sir Robert Ball; and then down to the present time "Large Telescopes" (1937) by the Astronomer Royal, and "Links with the Past in the Plant World" (1938) by Sir Albert Seward. That the artistic and literary side of the Institution has not been neglected may be gathered from the fact that Prof. Henry Morley and Prof. S. R. Gardiner delivered courses of lectures on "Chaucer and the English Writers" and "On the History of England" respectively. Amongst modern writers who have spoken at the Institution may be mentioned Mr. John Drinkwater, Mr. J. B. Priestley and Sir William Rothenstein.

To commemorate the centenary of the Institution, an appeal has been launched to enable some alterations and additions to be made to the old buildings. At the centenary dinner, held at the Criterion Restaurant on January 16, the president (Mr. R. S. Whipple), replying to the toast of "The Institution", which had been proposed by Sir Ian Fraser, mentioned that the sum of $£ 1,327$ had been promised-a good beginning, although much more is required. Sir Robert Waley Cohen proposed the health of the visitors, to which the Mayor of St. Pancras and Prof. Allan Ferguson replied. The latter dwelt on the usefulness of institutions such as that of Highgate as centres of intellectual activity.

\title{
Additional Evidence of Early Man in America
} WURTHER particulars of the Borax Lake site,
Lake County, California, on which relics of the
Folsom and the earlier Mohave Lake cultures have
been found, are made available in a preliminary
report to the Carnegie Institution, Washington, by
Mr. M. R. Harrington of the South Western Museum,
Los Angeles, who was engaged in exploratory
investigation there from July 1937 until June
1938.

The bed of Borax Lake is now dry, except for a little saline water at the north-west end. It is surrounded by hills, $300-400 \mathrm{ft}$. high ; but at the southeast it is separated from the Clear Lake basin by a ridge $100 \mathrm{ft}$. high only. A number of small canyons drain into the lake bed. Their alluvial fans are insignificant, with one exception, on which is evidence of human occupation over a considerable period going back to a time even before the formation of the fan began.

On the surface, Folsom and Mohave points occurred with other elements of the two cultures, as well as a certain archaic type of stemmed projectile point, now named 'Borax Lake' from its relative abundance. With these were a few modern chipped obsidian points. Excavation revealed abundant artefacts at a depth of five and a half feet in dark-coloured soil, and occasional finds in the underlying yellow gravels, sands and clays to a depth of eight feet. No true Folsom or Mohave points were found below the surface, but 'Silver Lake' points of the Mohave complex, Borax Lake points and a 'willow-leaf' type occurred. A keeled type was abundant in the lower part of the deposit with large scrapers and combined chopperscrapers. Smaller scrapers appeared practically throughout. Metatés, hammer-stones and pestles were found, but no shell or bone implements.

It is suggested that occupation, possibly seasonal, began with the pluvial which followed the Pleistocene ice age, and was abandoned at its close, when desiccation set in.

At the same time exploration and partial excavation of caves in south central Oregon, carried out from 1934 onward by Dr. L. S. Cressman, professor of anthropology in the University of Oregon, would now appear likely to have an important bearing on the date of man's appearance on the American continent. These caves, situated in what is now an extension of the Great Basin of the United States, were produced by the wave action of glacial lakes formed in dammed valleys during the Pleistocene period. On the recession of the ice and the onsetting of gradual desiccation the lakes disappeared, leaving the caves high and dry. One cave explored, for example, is two hundred feet above the valley floor. The caves were then occupied by man for some considerable time. Dr. Cressman has excavated occupational debris to a depth of nine feet or more.

In a preliminary report, also addressed to the Carnegie Institution, on excavations in 1937 at Catlow Valley and in three other localities, which were supported financially by the Institution, it is stated that numerous artefacts were discovered. These included basketry, sandals and black, undecorated potsherds. Faunal bones indicate a change of diet from mainly waterfowl and small rodents in the lower levels to large mammals, deer, bison and mountain sheep, in the upper.

Of two finds of human skeletal remains, one, consisting of a skull and other parts, was embedded about six inches deep in gravels at the north end of the cave and almost under the rear wall. This was about seven feet below the surface of the cave deposits. Absence of clear stratification in the cave invests this discovery with some ambiguity; but Dr. Cressman inclines to the view that the body was deposited in the gravels by wave action, when it was partially decomposed, but still covered with flesh, thus accounting for the unscratched condition of the bones and the circumstances of deposit. This could have happened only when the lake had begun to fall, but storm waters still invaded the cave, that is, not more than 15,000 years ago. It is, therefore, in Dr. Cressman's view, "entirely likely that we have here a representative of early man in the New World".

In two cave sites, one at Paisley and one at Fort Rock, a layer of pumice overlay the earliest evidence of human occupation. The earlier of these, that at Paisley, is assigned to an age of about 10,000 years.

In view of the abundance of fresh water and game in this early period, Dr. Cressman concludes not only that numerous traces of early man will be found in this area, but also that it may have served as the line of advance to Central America of the Asiatic immigrants. 